\title{
LIVELIHOOD OF FARMERS IN THE PROCESS OF INDUSTRIALIZATION - EVIDENCE FROM THE RECOVERY OF AGRICULTURAL LAND IN VIETNAM
}

\author{
Nguyen Duc Huu \\ Faculty of Social Work, Vietnam University of Trade Union \\ DOI: https://doi.org/10.51193/IJAER.2021.7112
}

\begin{abstract}
Ensuring the livelihoods of labour groups in the process of social development in Viet Nam has been demonstrated in previous studies. Many studies have found that labor can improve the livelihood model by using the right livelihoods. However, for labor in agricultural production, land is a great livelihood because it is the main input factor. Industrialization and urbanization have narrowed the area of agricultural production land and brought the livelihoods of farmers into another choice. Continued agricultural production in the absence of land or acceptance of conversion to a new livelihood model. Study attempted to quantize the impact of industrialization on aspects of farmers' lives. The study seeks to identify changes in livelihood strategies associated with the livelihood efficiency of the group with land recovery and non-land recovery during the strong industrialization and urbanization in Vietnam.
\end{abstract}

Keywords: Livelihoods, industrialization- urbanization, farmers, Vietnam

\section{INTRODUCTION}

Ensuring the livelihoods of working groups in the development process in Viet Nam has been demonstrated in previous studies. Many studies have found that labor can improve livelihood models by using appropriate livelihood capital. However, for labor in agricultural production, land is a great livelihood because it is the main input. (IAU) has narrowed the area of agricultural production land and put the livelihoods of farmers into another choice. Continue agricultural production in the absence of land or accept the transition to a new livelihood model.

The study analyzed the impact of both positive and negative aspects of the (IAU) process on the livelihoods of farmers who had their land revoked. The way farmers use compensation from land 
reclaims, and this also sets gaps in the government's post-compensation policy for converting farmers' livelihoods.

The current rescue team has attempted to determine in a way the effect of (IAU) on aspects of farmers' lives. The study seeks to identify changes in livelihood strategies associated with the livelihood efficiency of the group that has been recovered and not recovered during the strong (IAU) process in Vietnam.

\section{RESEARCH METHODS}

Analyzing the livelihoods of farmers who had their agricultural land revoked during the (IAU) process, the study was conducted with 300 dosing samples and 20 quasi-quasi-quasi-quasisamples as the number of households recovered by the government between 2008 and 2013. The study analyzed the livelihood characteristics of farmers before and after the land was recovered. The study shows the link between livelihood capital, livelihood model and current livelihood outcomes.

In order to determine the impact of agricultural land recovery on farmers' livelihoods, a comparative analysis based on quadative results among land-recovered and non-recovered households was described in detail by the study. It answers the question of whether land recovery has a significant impact on farmers' livelihoods and what is a direct impact on the transformation of their livelihoods. 


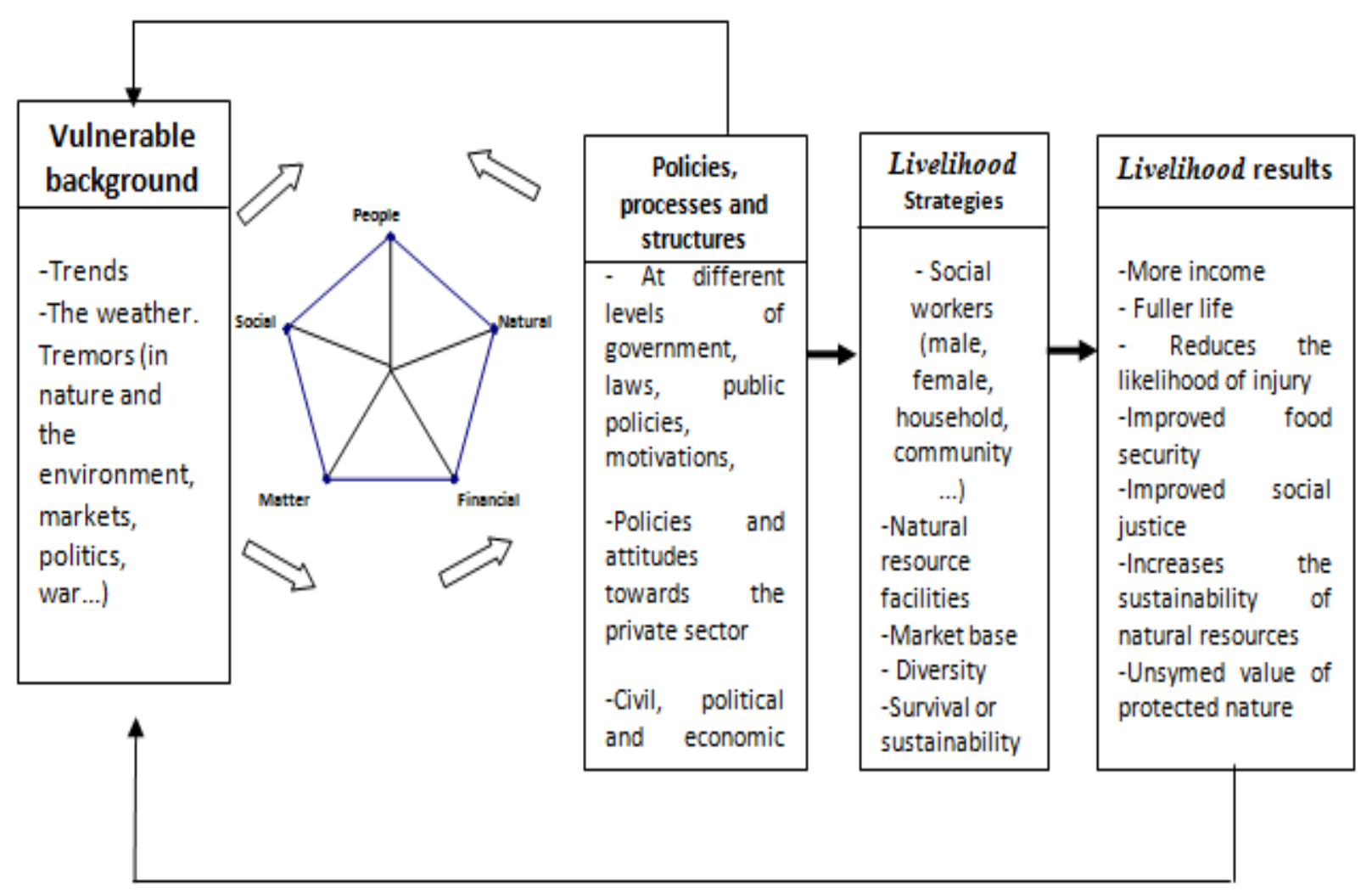

\section{Sustainable Livelihood Framework Source: DFID (2001)}

Mof livelihood cells of the group of farmers who lost land within the survey range are divided into 3 basic forms.

- The livelihood model group is based mainly on agricultural land (the remaining land area after being recovered or leased new land): rice cultivation, crops, livestock, poultry....

- Mixed livelihood model group: income of farmers based in part from agricultural activities (rice cultivation, crops, livestock, poultry) combined with non-agricultural activities (small trade, free labor..)

- The livelihood model group is based mainly on non-agricultural occupations and jobs: Working as workers in technology parks, trading, services, free employment...

Livelihood outcome: as a result of the impact between independent variables and dependent variables. Livelihood results in the diss currently expressed in such as income, employment status and living conditions. 


\section{RESEARCH RESULTS (Haiduong province, North Vietnam)}

- Characteristics of livelihood capital (natural, physical, human, social and financial capital)

- The relationship between livelihood capital sources and livelihood models (agriculture, non-agriculture, mixed)

- The link between livelihood capital characteristics, livelihood model and livelihood outcomes (employment, income and living ability)

\subsection{Human capital}

The level of labor is a problem that cannot be solved in a year or a few years, it is also a negative factor that hinders development with Hai Duong province in particular and the country in general. Many foreign investment enterprises face many difficulties in the process of recruiting skilled workers, high-tech workers even for those who already have a degree. The new training process as well as retraining before working as a procedure that many businesses have been having to accept.

Not only lack of human resources on direct production, skilled human resources, engineers with management qualifications, technicians, management positions are also very lacking and weak. This increases the investment cost of the business, reducing the competitiveness in attracting foreign as well as domestic investors of Hai Duong province.

According to statistics, the proportion of trained workers in Hai Duong by 2010 has reached $40 \%$ of the workforce, but training workers at the intermediate level or higher are still quite low only about $16 \%$ of the workforce (see table 1). 
International Journal of Agriculture and Environmental Research

ISSN: 2455-6939

Volume: 07, Issue: 01 "January-February 2021"

Table 1: Current status of labor according to hai Duong's training level

\begin{tabular}{|c|c|c|c|c|}
\hline Training level & 2000 & 2005 & 2009 & 2010 \\
\hline I. TOTAL (person) & 888.666 & 942.186 & 961.315 & 971.600 \\
\hline II. STRUCTURE (\%) & 100 & 100 & 100 & 100 \\
\hline 1. Un trained & 77,50 & 71,00 & 62,00 & 60,00 \\
\hline 2. Occupational primary & 1,70 & 2,50 & 4,47 & 5,00 \\
\hline 3. Technical workers are not equal to & 15,00 & 17,50 & 18,68 & 19,00 \\
\hline 4. Vocational intermediate & 2,00 & $\overline{2,70}$ & 4,81 & $\overline{5,00}$ \\
\hline 5. Vocational colleges & 0,30 & 0,40 & 0,84 & 0,86 \\
\hline 6. Professional intermediate & 1,80 & 2,80 & 3,15 & 3,16 \\
\hline 7. College & 0,95 & 1,40 & 2,05 & 2,10 \\
\hline 8. University & 1,05 & 2,00 & 3,87 & 4,00 \\
\hline 9. On college & 0,02 & 0,06 & 0,12 & 0,15 \\
\hline
\end{tabular}

(Source: Hai Duong DoLISA, 2012)

Hai Duong's population is in its youth. Every year more people enter working age than those who are out of working age; The results of the 2012 workforce survey showed that the labor force in the province is quite large, the majority of households have 2-4 employees. Young workers are favorable for cultural and professional training and income raising for farmers but this creates pressure on employment. The increase in the number of workers in both urban and rural areas has a significant impact on the goal of reducing the local unemployment rate. On the other hand, the labor market increasingly needs skilled and professional workers but in fact the majority of the province's laborers are unsym skilled, professional, un trained. The labor structure of 15 years and older has changed over the years: agricultural, forestry and aquaculture labor has decreased the most, self-production and business, service labor, non-agriculture have also decreased, instead of the increase of labor in the field of industry, construction, wage labor.

\subsection{Natural capital}

Rural industrialization is like a two-way door. On the one another, it opens up job opportunities for young workers, who have the opportunity to learn career skills to develop themselves. On the other side, that door is also closed to older labor groups, they are accustomed to agricultural production for many generations, now there is no land for cultivation. Workers in agriculture are considered "ageless" workers, while health is also able to work. Rural industrialization does not 
International Journal of Agriculture and Environmental Research

ISSN: 2455-6939

Volume: 07, Issue: 01 "January-February 2021"

give them the opportunity to change careers when their working age is not accepted by businesses.

Currently, in Hai Duong province when the State recovers land to carry out projects, the most effective method of compensation is monetary compensation. Along with compensation for damages, the support for career transformation is also done in cash. Basically, most people want compensation and support in this form because for farmers having a large amount of cash is their dream. Thus, natural capital (land) is converted into financial capital. Previously, land was an important means of generation of livelihoods of farmers, now converted into a sum of money. To ensure long-term livelihoods, this capital must be used by households for the purpose of investing in production to create income sources or apprenticeships to transform careers (human capital). If this money is used for the purpose of building houses, procuring property (material capital) and other purposes, the livelihood of people in the long run will be difficult. When livelihoods are difficult, they will be limited in education, medical examination and treatment, access to information ... That is, when farmers' agricultural land is recovered, they may also lose the opportunity to develop themselves, their families and social outreach.

\subsection{Material capital}

Notably, social infrastructure also achieved many important achievements. Schools at all levels are gradually built according to standards and socialization. Four new high schools have been built; built 94 additional preschool classrooms, 80 classrooms for primary school, 99 classrooms for secondary school, 118 classrooms for high school. By the end of 2014, 30.8\% of communes had reached criteria no. 5 in schools.

Information technology infrastructure has developed to remote and remote communes. Highspeed internet has reached most of the commune's cultural post offices, about $55 \%$ of communes have public Internet access points, $3 \mathrm{G}$ coverage has reached over $80 \%$ of the population, the percentage of communes with public phones is $100 \%$. Most people in rural areas have access to universal postal and telecommunications services. By the end of 2014, 86.2\% of communes achieved criterion No. 8 in post office. At the same time, cultural facilities are focused on construction and upgrading. $84.8 \%$ of communes have commune cultural and sports centers, $86 \%$ of villages have cultural houses/community houses, $88.65 \%$ of villages are recognized as cultural villages. By the end of 2014, 67.9\% of communes meeting criteria No. 6 in terms of cultural facilities. (PPC, 2014)

The rural market system has also been upgraded and renovated. The total investment capital for renovation and construction of rural markets in 2010-2013 reached VND 2,783 billion, mainly socialized capital and other capital sources (nearly $80 \%$ ).. Building a rural market with new rural 
International Journal of Agriculture and Environmental Research

ISSN: 2455-6939

Volume: 07, Issue: 01 "January-February 2021"

standards gradually removes temporary markets, land, thatmed roofs, focuses on upgrading and renovating in a solid and semi-permanent way... To date, $57.6 \%$ of communes have markets; of which, there are 84 wholesale markets of regional and provincial agricultural products. In terms of market management model, besides the traditional market management board, there were 194 cooperatives, 401 enterprises participating in trading and market management. By the end of $2014,45 \%$ of communes achieved criteria no. 7 on rural markets. (PPC,2014)

In general, material capital in rural areas of Hai Duong in the process of industrial security and DTH is upgraded and developed strongly. Although there are still certain limitations, this capital creates favorable and effective access for people in production activities, improving livelihoods

\subsection{Financial capital}

Capital is a limited resource for the economic sector in general, agriculture in particular. Production capital is constantly mobilized: from the scope of production to the range of circulation and return to production. Capital in agriculture is expressed by money of labor materials and labor subjects used in agricultural production. In order to develop a sustainable agriculture, in order to ensure national food safety, increase agricultural exports and transform rural economic structure, diversify agriculture, the first and decisive issue is capital.

Lack of capital is a major barrier to expanding production scale and increasing livestock crop yields in current surveyed farmers. The survey results showed that the surveyed households lacked both capital for production and capital for consumption, of which the lack of capital for production was mainly.

Research on borrowing sources and maximum borrowing capacity of local farmers surveyed showed that although people can borrow in many different sources, their maximum borrowing capacity is very low. There is no capital that farmers can borrow on average / 1 household to 21 million because of the specific policy of each bank and credit institutions, because people lack collateral ... On the other side, people can not borrow at the same time from multiple sources (excluding relatives, only small loans and private loans are subject to very high interest rates). Most farmers are able to borrow capital but the average loan per household is low, the ability to borrow between households loses land and does not lose land with little difference.

The survey results showed that $80.3 \%$ of households are able to borrow from banks, $8 \%$ of households can borrow from credit funds, $27.4 \%$ of households can borrow from relatives, $6.1 \%$ of households can borrow from other sources. On average, each household can borrow a maximum of VND 13.8 million, can borrow a maximum credit fund of VND 14.68 million, borrow relatives up to VND 6.4 million and borrow other sources up to VND 5.04 million. In terms of escalating 
prices and production characteristics of localities today, with the maximum amount of capital that farmers can borrow so, the expansion of production scale will face many difficulties. Therefore, it can be concluded that the capital limit that farmers can borrow is low as a barrier to the economic development of farmers.

Considering the source of capital that can be borrowed by farmers according to economic conditions, the higher the income, the greater the likelihood of borrowing. Although most poor people can borrow from the Bank for Social Policy, their ability to borrow from all other sources of capital is very poor, besides borrowing from the Bank for Social Policy always faces barriers such as: there must be a loan , low loan limits, borrowers must be participants of organizations ... Therefore, low income is also a barrier to borrowing.

\subsection{Social capital}

In this study, social capital is considered in aspects such as family relations, local customs and cultures, community laws and institutions, the role of organizations and social politics... in supporting farmers to access new livelihood models. For farmers who have lost land, social capital can be considered as a direct resource, an important factor for development in the era of industrialization and modernization.

For the government, the survey shows that government representatives have different roles in community-ed networks. There is no denying the role of local officials but people's beliefs and relationships in these representatives have certain levels.

\section{DISCUSSED}

Current research has sought to identify the characteristics of livelihood capital in choosing livelihood models suitable for farmers with agricultural land for easterly land.

The importance of this study is to assess the impact of the (IAU) process on the overall context of livelihoods, the study shows that this is really the core factor affecting the livelihood strategy of farmers. (IAU) is like a process of "natural selection" so that farmers can manage to adapt, survive and develop. The study found no significant differences in the group of land recovered and no land recovery in the selection of livelihood models. Farmer groups can fully develop suitable livelihood models when they rely on other capital sources (human capital, social capital, financial capital...) in addition to natural land

The team hopes that employment policies for land-revoked farmers in Vietnam need to find alternatives by identifying the livelihood capital they currently have. This will be more effective 
in ensuring a sustainable livelihood model instead of supporting compensation and unfea feasible vocational training classes.

\section{CONCLUSION}

Current research shows that there is no difference in choosing livelihood models between those who have had their land revoked and agricultural land recovered. The effectiveness of rice cultivation brings low value so the recovery of rice land of farmers does not affect the livelihood results. In fact, although many farmers do not have their land revoked, livelihood activities are not associated with agriculture, and they lend land or abandon land to other farmers to choose other livelihood models for higher efficiency (non-agricultural)

The study found that it was the process of (IAU) that directly affected the selection of livelihood models suitable for farmers. The (IAU) process creates new opportunities for farmers to have jobs with higher incomes (working as workers in industrial parks or providing other essential services).

The planning and implementation of policies in ensuring sustainable livelihoods for farmers must really stem from the context of CNH- DTH. The current livelihood resources of land-recovered farmers must be considered as databases before taking into account the purpose and effectiveness of supporting policies.

\section{REFERENCES}

Do Kim Chung (January 2000), "Land Market in Agriculture in Vietnam - Status and Policy Directions", Journal of Economic Research.

Nguyen Sinh Cuc (2008), "Development of industrial parks in the Red River Delta and the issue of farmers losing agricultural land", National Political Publishing House, Hanoi.

Bui The Cuong (2010), Contributing to understanding social change in Vietnam today, Social Sciences Publishing House.

Hoang Van Cuong (September 2006), "Employment issues for people with land receding in industrial parks", Vietnam Industrial Park Magazine.

Hai Duong Province Statistical Office (2012), Hai Duong Statistical Yearly, Hanoi.

Pham Chanh Duong (1/2003), "On the implementation of compensation policy in the development of industrial parks", Communist Magazine.. 
Chambers, R. a. (1992). Sustainable rural livelihoods: practical concepts for the 21st century IDS,. IDS Discussion Paper No 296.

Chaudhry. P and Ruysschaert, R. (2007), "Climate Change and Human Development in Vietnam: A case study”, Human Development Report 2007: Vietnam Case Study.

Chayanov, A. (1998. ). The New Palgrave Dictionary of Economics. London: Vol.1, Macmillan.

Coleman, J. (1992). Characterization of the Escherichia coli gene for 1-acyl-sn-glycerol-3phosphate acyltransferase. March II 1992, Volume 232, Issue 2, pp 295-303.

Coleman, J. S. (1988). Social Capital in the Creation of Human Capital. The American Journal of Sociology 94, S95-S120.

Diana Carney. (1998): "Implemeting the Sustainable Livelihood Approach", chapter 1 in D. Carney (ed), Sustainable Rural Livelihoods: What Contribule Can We Make?, London: Department for International Development.

Dasgupta, S. et. al (2007), "The Impact of Seal level Rise on Developing Countries: A Comparative Analysis", World Bank Policy Research Working Paper 4136, February 2007.

DFID (2001), “Susstainable Livelihoods Guidance Sheets”, DFID Report 